\title{
The five primary prostaglandins stimulate contractions and phasic activity of the urinary bladder urothelium, lamina propria and detrusor
}

\author{
Zane Stromberga, Russ Chess-Williams and Christian Moro* ${ }^{*}$
}

\begin{abstract}
Background: Inflammation is often associated with several bladder dysfunctions, including overactive bladder $(\mathrm{OAB})$ and interstitial cystitis/bladder pain syndrome (IC/PBS). As such, inflammation of the bladder and the actions of inflammatory mediators may contribute to the development of urinary symptoms. This study assessed the actions of $\mathrm{PGE}_{2}, \mathrm{PGF}_{2}, \mathrm{PGD}_{2}, \mathrm{TXA}_{2}$, and $\left.\mathrm{PG}\right|_{2}$ on urinary bladder urothelium with lamina propria (U\&LP), and detrusor smooth muscle.

Methods: Studies were carried out using isolated tissue baths, where strips of porcine bladder U\&LP or detrusor were exposed to varying concentrations of prostaglandin agonists ( $1 \mu \mathrm{M}$ and $10 \mu \mathrm{M})$.

Results: All assessed prostaglandin agonists contracted both the U\&LP and detrusor smooth muscle, with the rank order of contractile response effectiveness as: $P_{G E_{2}}>P G F_{2 a}>T X A_{2}>P G_{2}>P G I_{2}$. In U\&LP, treatment with $P G E_{2}$ $(10 \mu \mathrm{M})$ increased tonic contractions by $1.36 \pm 0.09 \mathrm{~g}(n=42, p<0.001)$ and phasic contractions by $40.4 \pm 9.6 \%(n=$ $42, p<0.001)$. In response to $\mathrm{PGF}_{2 a}(10 \mu \mathrm{M})$, U\&LP tonic contractions increased by $0.79 \pm 0.06 \mathrm{~g}(n=14, p<0.001)$ and phasic activity by $13.3 \% \pm 5.3 \%(n=15, p<0.05)$. In detrusor preparations, $\mathrm{PGE}_{2}(10 \mu \mathrm{M})$ increased tonic contractions by $1.32 \pm 0.13 \mathrm{~g}(n=38, p<0.001)$ and $\mathrm{PGF}_{2 a}(10 \mu \mathrm{M})$ by $0.97 \pm 0.14 \mathrm{~g}(n=12, p<0.001)$. Only $34 \%(n=$ 48) of all detrusor preparations exhibited spontaneous activity prior to the addition of any agonist at a frequency of $2.03 \pm 0.12 \mathrm{cpm}$. In preparations that did not exhibit initial phasic activity, all of the prostaglandin agonists were capable of commencing phasic activity.

Conclusions: The urinary bladder U\&LP and detrusor respond to a variety of prostaglandin agonists, with their activation resulting in direct contractions, as well as increases to spontaneous contractile activity. This study presents the prostaglandin receptor system as a potential therapeutic target for lower urinary tract dysfunction.
\end{abstract}

Keywords: Inflammation, Prostaglandins, Urinary bladder, Urothelium, Detrusor

\footnotetext{
* Correspondence: cmoro@bond.edu.au

Centre for Urology Research, Faculty of Health Sciences and Medicine, Bond

University, Gold Coast, Queensland 4226, Australia
}

(c) The Author(s). 2020 Open Access This article is licensed under a Creative Commons Attribution 4.0 International License, which permits use, sharing, adaptation, distribution and reproduction in any medium or format, as long as you give appropriate credit to the original author(s) and the source, provide a link to the Creative Commons licence, and indicate if changes were made. The images or other third party material in this article are included in the article's Creative Commons licence, unless indicated otherwise in a credit line to the material. If material is not included in the article's Creative Commons licence and your intended use is not permitted by statutory regulation or exceeds the permitted use, you will need to obtain permission directly from the copyright holder. To view a copy of this licence, visit http://creativecommons.org/licenses/by/4.0/ The Creative Commons Public Domain Dedication waiver (http://creativecommons.org/publicdomain/zero/1.0/) applies to the data made available in this article, unless otherwise stated in a credit line to the data. 


\section{Background}

The involvement of prostaglandins in bladder physiology was first recognised from their release after urinary bladder distension or injury to the urothelium $[1,2]$. An increase of prostaglandins in the urine of patients suffering from $\mathrm{OAB}$ has been well-reported previously [3-6], suggesting the prostaglandin system as a potential future therapeutic target in various bladder dysfunctions. The exact role and mechanisms of endogenous prostaglandins in the urinary bladder are not well understood. However, previous studies utilising exogenous prostaglandins have shown that these chemicals can alter contractility and micturition reflex in human bladders [7].

Prostaglandin production is generally low in healthy tissue but can increase immediately following acute inflammation [8]. They are synthesised in the bladder by cyclooxygenase (COX) and then subsequently converted into five primary prostanoids via their respective synthases: $\mathrm{PGE}_{2}, \mathrm{PGD}_{2}, \mathrm{PGF}_{2 \alpha}$, prostacyclin $\left(\mathrm{PGI}_{2}\right)$ and thromboxane $\left(\mathrm{TXA}_{2}\right)$ [9]. Prostaglandins are synthesised in both the bladder urothelium with lamina propria (U\&LP) and in detrusor smooth muscle in response to stretch, nerve stimulation, U\&LP damage or other inflammatory mediators $[10,11]$. The production of prostaglandins is determined by the cells present at sites of inflammation capable of synthesising prostaglandins and the activity of the two cyclooxygenase isoenzymes, namely COX-1 and COX-2. For example, macrophages predominantly generate $\mathrm{PGE}_{2}$ and $\mathrm{TXA}_{2}$, whereas mast cells produce $\mathrm{PGD}_{2}$ [12]. COX-1 is present in most cells, whereas the expression of COX-2 is generally low in cells, but can increase dramatically upon stimulation by immune cells [13]. Prostaglandin $I_{2}$ is the main prostaglandin synthesised in the human bladder, followed by $\mathrm{PGE}_{2}, \mathrm{PGF}_{2 \alpha}$ and TXA $2[14,15]$.

Although past studies have explored the effects of the different prostaglandins on the urinary bladder with a large focus on the actions of $\mathrm{PGE}_{2}$, a complete understanding of the contractile effects of the other four prostaglandins on the urinary bladder remain unclear. Specifically, of interest is to determine how the actions of the prostaglandins affect urothelium with lamina propria that is separated from the detrusor smooth muscle. Therefore, this study aimed to assess the influence of $\mathrm{PGE}_{2}, \mathrm{PGF}_{2 \alpha}, \mathrm{PGD}_{2}, \mathrm{TXA}_{2}$ and $\mathrm{PGI}_{2}$ on the urinary bladder urothelium with lamina propria and detrusor smooth muscle contractions and phasic activity.

\section{Methods}

\section{Tissue preparation}

Urinary bladders were obtained from Large WhiteLandrace pigs (approximately six months old, weighing between 80 and $100 \mathrm{~kg}$ ) from the local abattoir after slaughter for the routine commercial provision of food.
All methods were carried out in accordance with relevant Australian guidelines and regulations, and all experimental protocols were in accordance the Australian Code of Practice for the Care and Use of Animals for Scientific Purpose [16]. As no animals were bred, harmed, culled, interfered, or interacted with as part of this research project, Animal Ethics Approval was not required for offal use [17]. Urothelium with lamina propria was dissected from the underlying detrusor layer, consistent with methods carried out in past studies [1821 , and cut in strips. Adjacent strips of U\&LP and detrusor $(10 \mathrm{~mm} \times 5 \mathrm{~mm})$ were tied vertically between an isometric force transducer (MCT050/D, ADInstruments, Castle Hill, Australia) and a fixed hook in $10 \mathrm{~mL}$ organ baths (Labglass, Brisbane, Australia), and superfused with Krebs-bicarbonate solution $(\mathrm{NaCl} 118.4 \mathrm{mM}$, $\mathrm{NaHCO}_{3} 24.9 \mathrm{mM}, \mathrm{CaCl}_{2} 1.9 \mathrm{mM}, \mathrm{MgSO}_{4} 2.41 \mathrm{mM}$, $\mathrm{KCl} 4.6 \mathrm{mM}, \mathrm{KH}_{2} \mathrm{PO}_{4} 1.18 \mathrm{mM}$ and D-glucose $11.7 \mathrm{mM}$ ) and carbogen gas (95\% oxygen and 5\% carbon dioxide) at $37{ }^{\circ} \mathrm{C}$. After tissue mounting, strips of U\&LP and detrusor were washed three times, tension adjusted to 1.5$2.0 \mathrm{~g}$ and tissues left to equilibrate for $30 \mathrm{~min}$. After the equilibration period, a single dose of a prostaglandin receptor agonist was added to the tissue strip.

\section{Pharmaceutical agents}

The following compounds were used in this study: prostaglandin $E_{2}$, prostaglandin $F_{2 \alpha}$, prostaglandin $D_{2}$, prostaglandin $\mathrm{I}_{2}$ and thromboxane $\mathrm{A}_{2}$ (U-46619, Cayman Chemicals, Michigan, USA). Prostaglandin $E_{2}$, prostaglandin $F_{2 \alpha}$, prostaglandin $D_{2}$, and prostaglandin $I_{2}$ were dissolved in $100 \%$ ethanol and diluted with distilled $\mathrm{H}_{2} \mathrm{O}$. U-46619 was supplied as a solution in methyl acetate, which was diluted with distilled $\mathrm{H}_{2} \mathrm{O}$. Two concentrations of each prostaglandin receptor agonists were selected, $1 \mu \mathrm{M}$ and $10 \mu \mathrm{M}$.

\section{Data analysis}

Data were graphed and analysed using GraphPad Prism version 8.3 for Windows (GraphPad Software, La Jolla, California, USA). Statistical analysis was conducted using a paired Student's $t$-test, where $p<0.05$ was considered as significant. All values were reported as mean change \pm SEM. $n$ equates to the number of individual bladders used in this study.

\section{Results}

Prostaglandin agonists for increasing U\&LP spontaneous phasic activity

Strips of U\&LP exhibited spontaneous phasic contractions in the absence of any stimulation at a mean frequency of $3.26 \pm 0.07$ cycles per minute (cpm, $n=146)$. Treatment with $\mathrm{PGE}_{2}$ caused the most prominent increases to U\&LP spontaneous contractile activity. When 


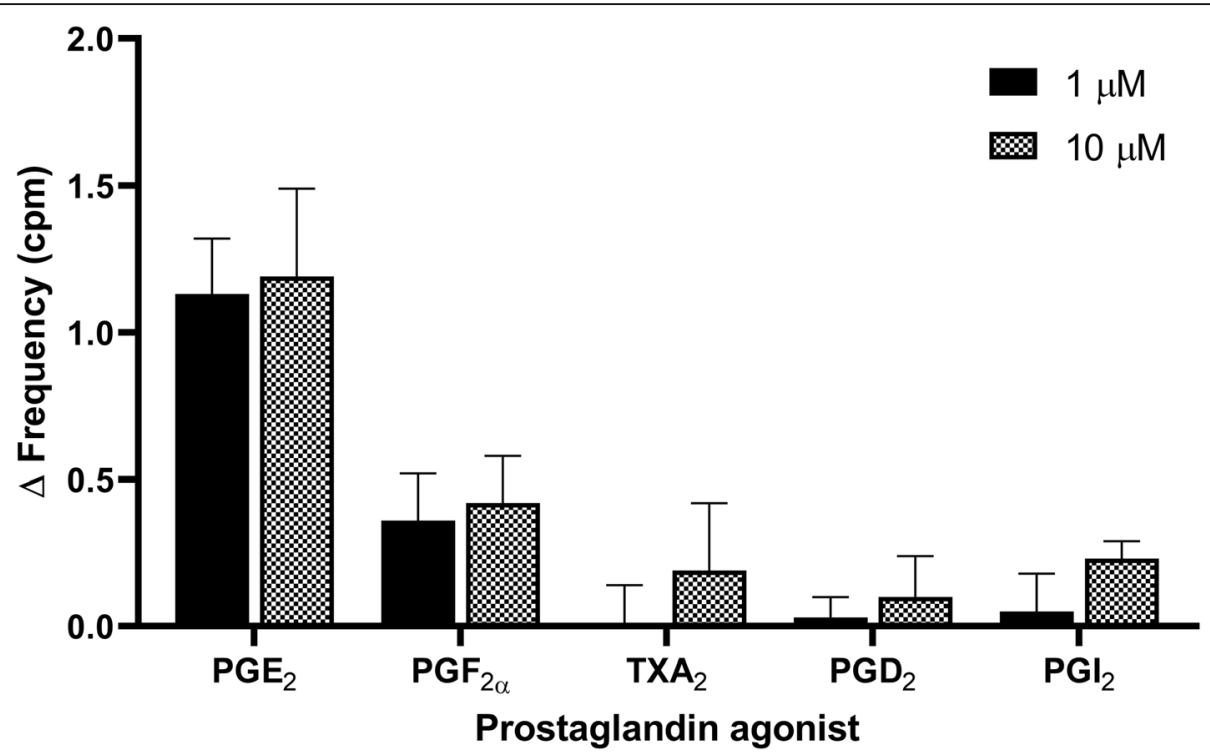

Fig. 1 U\&LP changes in the frequency of spontaneous phasic contractions after the treatment with $1 \mu \mathrm{M}$ and $10 \mu \mathrm{M}$ of each specific prostaglandin agonists $E_{2}, F_{2 a}, T X A_{2}, D_{2}$, and $I_{2}$. There were no statistically significant differences in frequency changes between the $1 \mu M$ and $10 \mu \mathrm{M}$ concentrations for any of the agonists (unpaired Student's 2-tailed t-test)

$\mathrm{PGE}_{2}(1 \mu \mathrm{M})$ was added to isolated tissues, spontaneous activity increased by $39.2 \% \pm 6.7 \%(n=38, p<0.001$, Fig. 1). A greater concentration of $\mathrm{PGE}_{2}(10 \mu \mathrm{M})$ showed similar increases of $40.4 \% \pm 9.6 \%$ to the U\&LP spontaneous activity $(n=42, p<0.001)$. Treatment with $\mathrm{PGF}_{2 \alpha}$ showed smaller increases of $10.5 \% \pm 4.6 \%$ to spontaneous activity when treated with $1 \mu \mathrm{M}(n=10, p<0.05)$ and $13.3 \% \pm 5.3 \%$ when treated with $10 \mu \mathrm{M}(n=14, p<0.05)$. The addition of $\mathrm{PGI}_{2}(10 \mu \mathrm{M})$ increased spontaneous activity by $6.2 \% \pm 1.6 \%(n=8, p<0.01)$ but had no effect at a lower concentration $(1 \mu \mathrm{M}, n=8)$. The frequency was not significantly affected by $\mathrm{PGD}_{2}(1-10 \mu \mathrm{M}, n=12)$ or $\mathrm{TXA}_{2}(1-10 \mu \mathrm{M}, n=16)$.

The average amplitude of these spontaneous phasic contractions exhibited in U\&LP strips in the absence of any stimulation was $0.57 \pm 0.02 \mathrm{~g}(n=146)$. In response to treatment with $1 \mu \mathrm{M} \mathrm{PGE}$, amplitude decrease of $0.14 \pm 0.04 \mathrm{~g}(n=38, p<0.001$, Table 1$)$ were observed. Similar decreases of $0.16 \pm 0.03 \mathrm{~g}$ were also observed in response to a higher $\mathrm{PGE}_{2}$ concentration $(10 \mu \mathrm{M}, n=42$, $p<0.01)$. Treatment with $\mathrm{TXA}_{2}(1 \mu \mathrm{M})$ showed a significant decrease in the amplitude by $0.28 \pm 0.06 \mathrm{~g}$ $(n=8, p<0.01)$, which was not observed at a higher concentration $(10 \mu \mathrm{M}, n=6)$. The addition of $\mathrm{PGI}_{2}$ $(10 \mu \mathrm{M})$ decreased amplitude of spontaneous activity by $0.14 \pm 0.05(n=8, p<0.05)$ but had no effect at a lower concentration $(1 \mu \mathrm{M}, n=8)$. The amplitude of spontaneous contractions was not altered by the addition of either $\mathrm{PGF}_{2 \alpha}(1-10 \mu \mathrm{M}, n=24)$ or $\mathrm{PGD}_{2}$ $(1-10 \mu \mathrm{M}, n=12$, Table 1$)$. None of the decreases in the amplitude of spontaneous phasic contractions of the U\&LP were significantly affected by the two different prostaglandin receptor agonist concentrations $(1 \mu \mathrm{M}$ and $10 \mu \mathrm{M})$.

\section{Prostaglandin agonists in stimulating phasic contractions in detrusor}

Total of $34 \%(n=48)$ of the detrusor preparations that were set up in the organ baths exhibited spontaneous activity prior to the addition of any agonists. These

Table 1 U\&LP changes in the amplitude of phasic contractions in response to the five primary prostaglandin agonists (mean \pm SEM)

\begin{tabular}{|c|c|c|c|c|c|c|}
\hline \multirow[b]{2}{*}{ Agonist } & \multicolumn{2}{|c|}{$1 \mu \mathrm{M}$ of agonist } & \multirow[b]{2}{*}{$n$} & \multicolumn{2}{|c|}{$10 \mu \mathrm{M}$ of agonist } & \multirow[b]{2}{*}{$n$} \\
\hline & Absence (g) & Presence (g) & & Absence (g) & Presence $(\mathrm{g})$ & \\
\hline $\mathrm{PGE}_{2}$ & $0.53 \pm 0.05$ & $0.40 \pm 0.03^{* * *}$ & 38 & $0.53 \pm 0.04$ & $0.37 \pm 0.03^{* *}$ & $\overline{42}$ \\
\hline $\mathrm{PGF}_{2 a}$ & $0.30 \pm 0.03$ & $0.29 \pm 0.01$ & 10 & $0.51 \pm 0.06$ & $0.46 \pm 0.08$ & 14 \\
\hline $\mathrm{TXA}_{2}$ & $0.90 \pm 0.16$ & $0.62 \pm 0.14^{* *}$ & 8 & $0.75 \pm 0.16$ & $0.71 \pm 0.25$ & 6 \\
\hline $\mathrm{PGD}_{2}$ & $0.59 \pm 0.10$ & $0.46 \pm 0.04$ & 4 & $0.55 \pm 0.08$ & $0.43 \pm 0.06$ & 8 \\
\hline$\left.P G\right|_{2}$ & $0.64 \pm 0.07$ & $0.56 \pm 0.07$ & 8 & $0.57 \pm 0.09$ & $0.43 \pm 0.06^{*}$ & 8 \\
\hline
\end{tabular}

${ }^{*} p<0.05,{ }^{* *} p<0.01,{ }^{* * *} p<0.001$. Paired Student's $t$-test 
contractions occurred at an average frequency of $2.03 \pm$ $0.12 \mathrm{cpm}(n=48)$ with an average amplitude of $0.26 \pm$ $0.02 \mathrm{~g}(n=48)$. However, the majority of the detrusor preparations, that were otherwise quiescent developed spontaneous phasic contractions after the addition of the agonist.

Of those detrusor preparations that did not exhibit initial phasic activity during baseline: $\mathrm{PGE}_{2}(1 \mu \mathrm{M})$ sparked contractions in $68 \%$ of preparations $(n=19)$ and $\mathrm{PGE}_{2}$ $(10 \mu \mathrm{M})$ in $69 \%(n=22)$; $\mathrm{PGF}_{2 \alpha}(1 \mu \mathrm{M})$ initiated contractions in in $56 \%(n=5)$ and $\mathrm{PGF}_{2 \alpha}(10 \mu \mathrm{M})$ in $88 \%(n=$ $7)$; $\operatorname{TXA}_{2}(1 \mu \mathrm{M})$ initiated contractions in $63 \%(n=5)$ and $\mathrm{TXA}_{2}(10 \mu \mathrm{M})$ in $80 \%(n=4) ; \mathrm{PGD}_{2}(1 \mu \mathrm{M})$ initiated phasic activity in $50 \%(n=2)$ and PGD $_{2}(10 \mu \mathrm{M})$ in $75 \%$ $(n=6)$; and lastly $\mathrm{PGI}_{2}(10 \mu \mathrm{M})$ initiated contractions in $40 \%(n=2)$ of preparations. This demonstrates the ability of prostaglandin agonists to induce spontaneous activity in otherwise quiescent detrusor tissue strips.

\section{Prostaglandin agonists in stimulating tonic contractions} in U\&LP

All assessed prostaglandin agonists contracted the U\&LP with the rank order of contractile response effectiveness as: $\mathrm{PGE}_{2}>\mathrm{PGF}_{2 \alpha}>\mathrm{TXA}_{2}>\mathrm{PGD}_{2}>\mathrm{PGI}_{2}$. The addition of $\mathrm{PGE}_{2}(1 \mu \mathrm{M})$ to isolated U\&LP induced tissue contractions, with increases of $1.01 \pm 0.08 \mathrm{~g}(n=38, p<0.001)$ to the tonic contractions. When a greater concentration of $\mathrm{PGE}_{2}(10 \mu \mathrm{M})$ was selected, increases of $1.36 \pm 0.09 \mathrm{~g}(n=$ $42, p<0.001$, Fig. 2) were observed. Treatment with $1 \mu \mathrm{M}$ $\mathrm{PGF}_{2 \alpha}$ showed a small increase to tonic contractions of $0.15 \pm 0.04 \mathrm{~g}(n=10, p<0.01)$ when compared to a higher concentration of $10 \mu \mathrm{M}$, which exhibited increases of $0.79 \pm 0.06 \mathrm{~g}(n=14, p<0.001)$. The addition of two concentrations of $\mathrm{TXA}_{2}$ induced similar contractions, where tonic contraction increased by $0.70 \pm 0.07 \mathrm{~g}$ when treated with $1 \mu \mathrm{M} \quad(n=8, p<0.001)$, and by $0.65 \pm 0.12 \mathrm{~g}$ after treatment with $10 \mu \mathrm{M}(n=6, p<0.001)$.
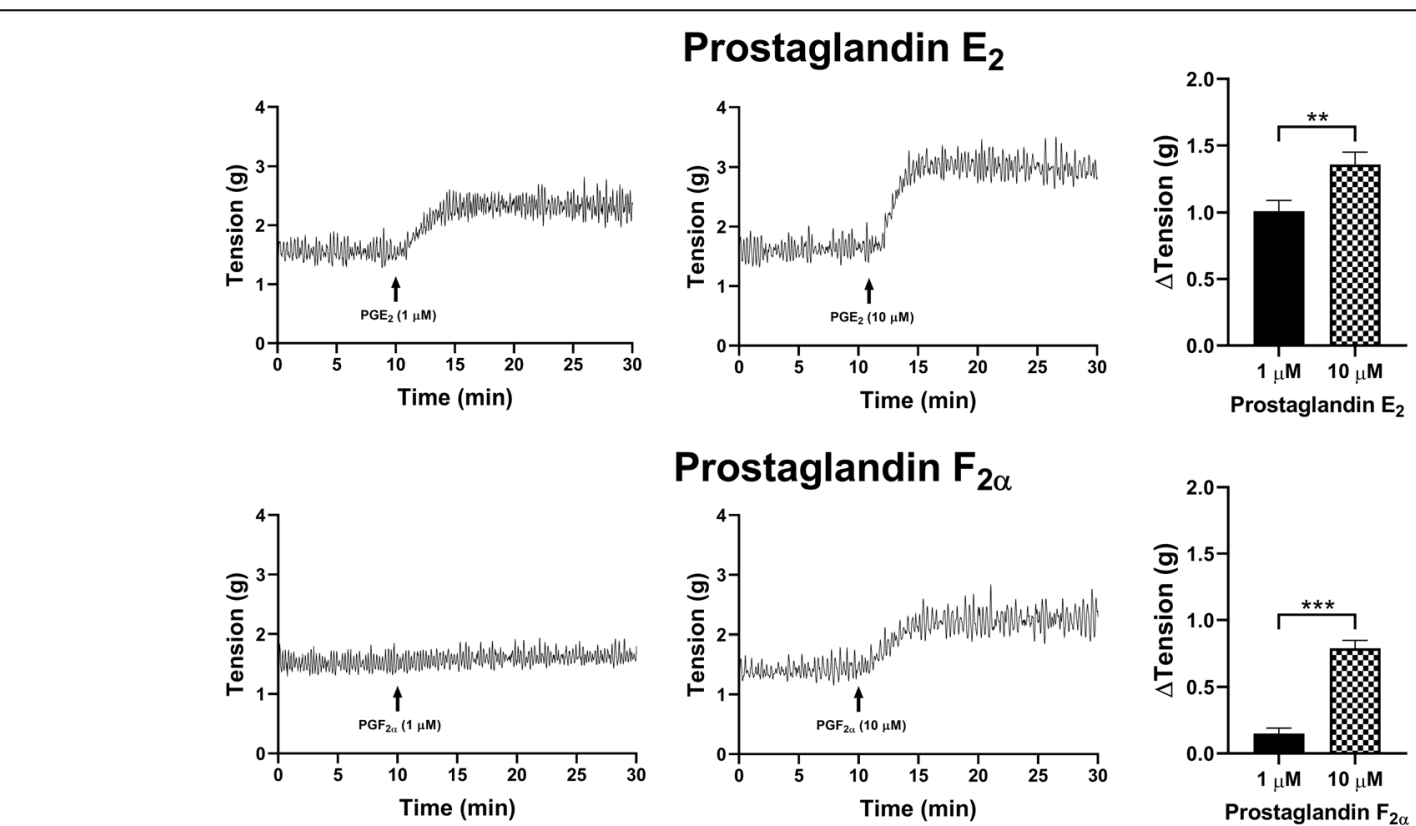

Prostaglandin $\mathbf{F}_{2 \alpha}$
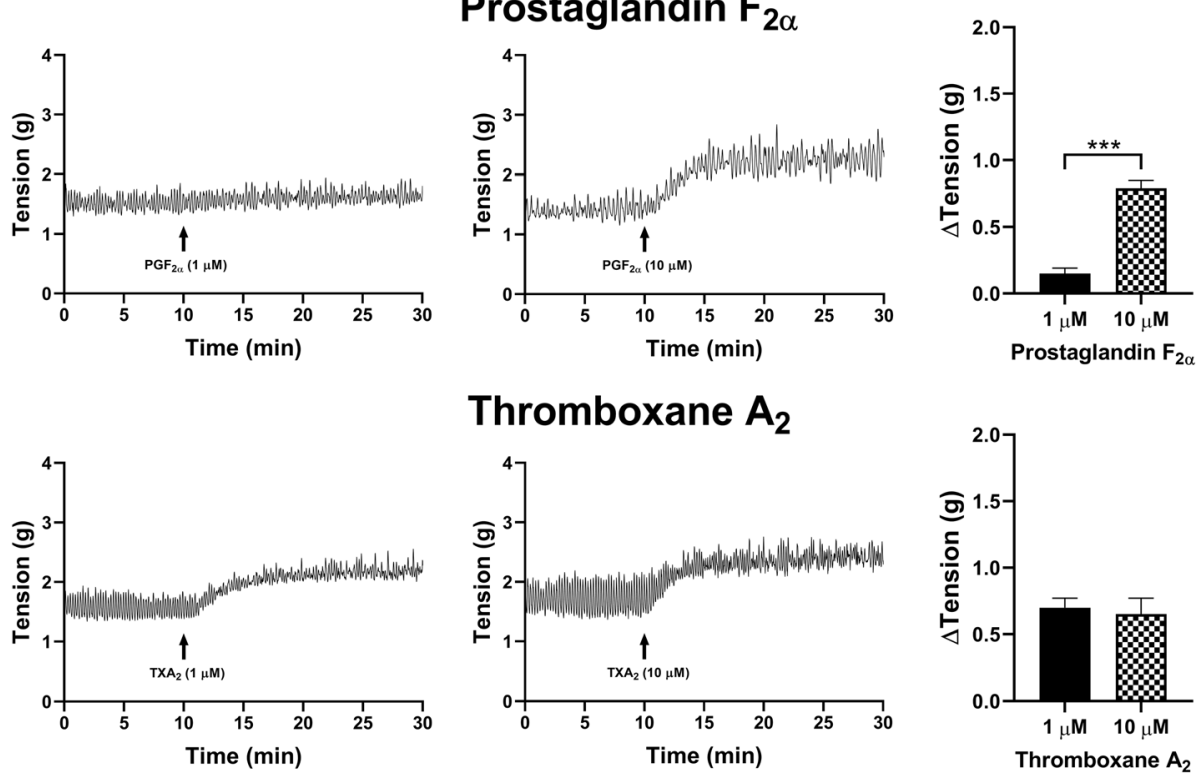

Fig. 2 U\&LP changes in tonic contractions in response to the treatment with $1 \mu \mathrm{M}$ and $10 \mu \mathrm{M}$ of prostaglandin $\mathrm{E}_{2}$ (top row), $\mathrm{F}_{2 a}$ (middle row) and $\mathrm{TXA}_{2}$ (bottom row). Sample traces of the responses observed to two concentrations of prostaglandin agonist (left \& middle columns). Increases in tonic contractions after treatment with each agonist are represented as mean change \pm SEM (right column). Significant changes in the tonic contractions between $1 \mu \mathrm{M}$ and $10 \mu \mathrm{M}$ were evaluated using an unpaired Student's two-tailed $t$-test, where ${ }^{*} p<0.05,{ }^{* *} p<0.01,{ }^{* * *} p<0.001$ 
When $\mathrm{PGD}_{2}(1 \mu \mathrm{M})$ was added to the U\&LP tissue preparations, tonic contractions increased by $0.19 \pm 0.04$ g $(n=4, p<0.05$, Fig. 3$)$. Treatment with a higher concentration of $\mathrm{PGD}_{2}(10 \mu \mathrm{M})$ exhibited increases of $0.63 \pm 0.09 \mathrm{~g}(n=8, p<0.001)$. The addition of $\mathrm{PGI}_{2}$ showed small increases in tonic contractions of $0.11 \pm$ $0.02 \mathrm{~g}$ in response to $1 \mu \mathrm{M} \mathrm{PGI} \mathrm{P}_{2}(n=8, p<0.001)$, and $0.22 \pm 0.03 \mathrm{~g}$ in response to $10 \mu \mathrm{M} \mathrm{PGI} 2(n=8, p<0.001$, Fig. 3).

\section{Prostaglandin agonists in stimulating tonic contractions in detrusor}

All assessed prostaglandin agonists contracted the detrusor smooth muscle preparations with the rank order of contractile response effectiveness as: $\mathrm{PGE}_{2}>\mathrm{PGF}_{2 \alpha}>$ $\mathrm{TXA}_{2}>\mathrm{PGD}_{2}>\mathrm{PGI}_{2}$. In detrusor preparations, $\mathrm{PGE}_{2}$ $(1 \mu \mathrm{M})$ increased the tonic contractions by $0.73 \pm 0.09 \mathrm{~g}$ $(n=34, p<0.001)$, whereas $\mathrm{PGE}_{2}(10 \mu \mathrm{M})$ nearly doubled the response, producing an average increase of $1.32 \pm$ $0.13 \mathrm{~g}(n=38, p<0.001$, Fig. 4). Treatment with $1 \mu \mathrm{M}$ $\mathrm{PGF}_{2 \alpha}$ showed a small increase of $0.20 \pm 0.05 \mathrm{~g}(n=10$, $p<0.01$ ), whereas $10 \mu \mathrm{M}$ of $\mathrm{PGF}_{2 \alpha}$ increased the tonic contractions by $0.97 \pm 0.14 \mathrm{~g} \quad(n=12, p<0.001)$. When $\mathrm{TXA}_{2}$ was added, tonic contractions increased by $0.47 \pm$ $0.12 \mathrm{~g}$ when treated with $1 \mu \mathrm{M}(n=8, p<0.001)$, and by $1.03 \pm 0.14 \mathrm{~g}(n=6, \mathrm{p}<0.001$, Fig. 4) when treated with $1 \mu \mathrm{M} \mathrm{TXA} 2$.

$\mathrm{PGD}_{2}$ showed a small increase in the tonic contractions of $0.12 \pm 0.04 \mathrm{~g}$ when $1 \mu \mathrm{M}$ was added $(n=4, p<$
$0.05)$, and an increase of $0.36 \pm 0.06 \mathrm{~g}$ when $10 \mu \mathrm{M} \mathrm{PGD}_{2}$ was added ( $n=6, \mathrm{p}<0.01$, Fig. 5$). \mathrm{PGI}_{2}$ showed small increases in tonic contractions at both concentrations, showing an increase of $0.16 \pm 0.02 \mathrm{~g}$ when treated with $1 \mu \mathrm{M}(n=8, p<0.001)$, and $0.13 \pm 0.03 \mathrm{~g}$ when treated with $10 \mu \mathrm{M} \mathrm{PGI}_{2}(n=8, p<0.001$, Fig. 5). The effects of prostaglandin agonists on tonic contractions of the detrusor smooth muscle were significantly different between the two concentrations $(1 \mu \mathrm{M}$ and $10 \mu \mathrm{M})$ for $\operatorname{PGE}_{2}(p<0.001), \operatorname{PGF}_{2 \alpha}(p<0.001)$ and $\operatorname{PGD}_{2}(p<0.05)$.

\section{Discussion}

Previous research has shown that stimulation of the M3 muscarinic receptor in U\&LP causes immediate contractions, as well as increases in the frequency of spontaneous phasic contractions, and reduction in their amplitude [22, 23]. In our study, the prostaglandin agonists have shown similar contractile responses to both tonic contractions and spontaneous activity, thereby associating the actions of prostaglandins with many of the bladder contractile dysfunctions, such as $\mathrm{OAB}$ and $\mathrm{IC} /$ BPS.

The ability to contract the tissue was varied between the different prostaglandin agonists. The rank order of agonist response in stimulating contractions in U\&LP and detrusor was: $\mathrm{PGE}_{2}>\mathrm{PGF}_{2 \alpha}>\mathrm{TXA}_{2}>\mathrm{PGD}_{2}>\mathrm{PGI}_{2}$. This furthers previous research which reported the involvement of $\mathrm{PGE}_{2}$ in the initiation of micturition in both humans and animals [24], suggesting a contribution

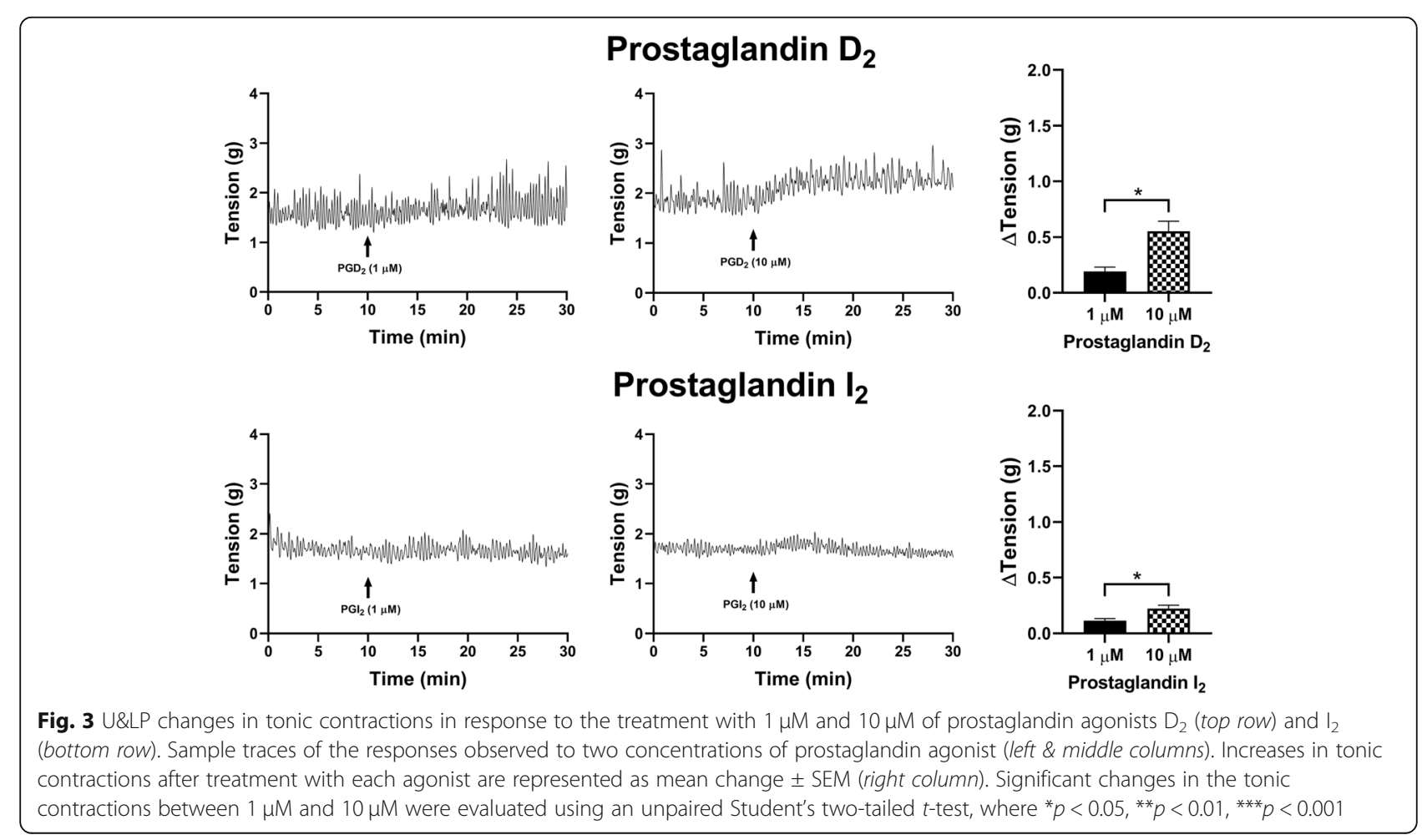




\section{Prostaglandin $\mathrm{E}_{2}$}
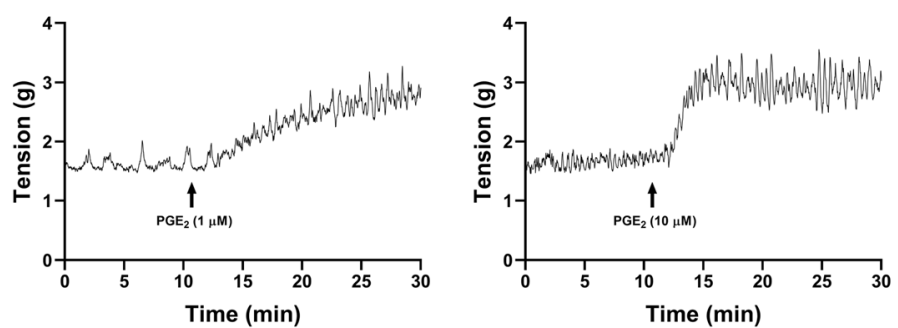

\section{Prostaglandin $\mathbf{F}_{2 \alpha}$}
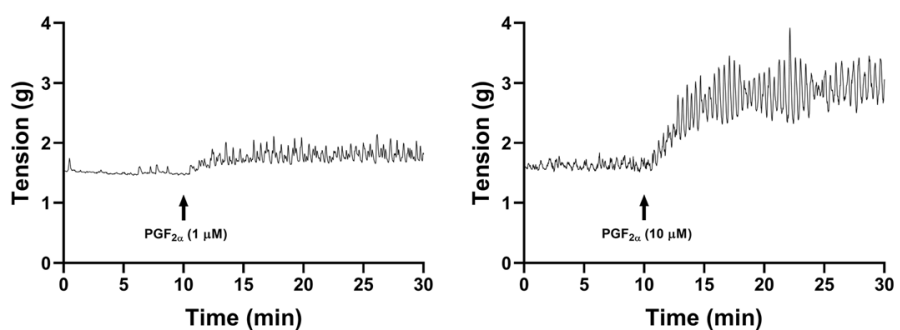

Thromboxane $\mathrm{A}_{2}$
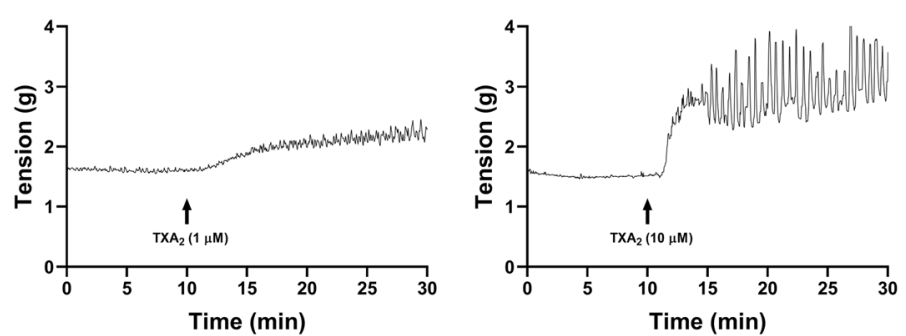
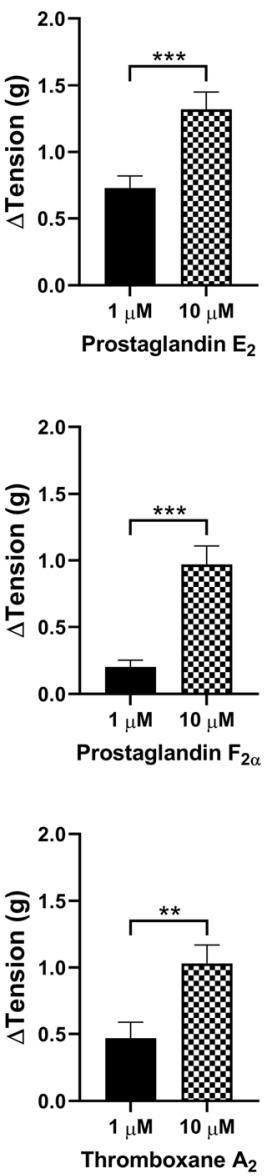

Fig. 4 Detrusor changes in tonic contractions in response to the treatment with $1 \mu \mathrm{M}$ and $10 \mu \mathrm{M}$ of prostaglandin $\mathrm{E}_{2}$ (top row), $\mathrm{F}_{2 a}$ (middle row) and TXA (bottom row). Sample traces of the responses observed to two concentrations of prostaglandin agonist (left \& middle columns). Increases in tonic contractions after treatment with each agonist are represented as mean change \pm SEM (right column). Significant changes in the tonic contractions between $1 \mu \mathrm{M}$ and $10 \mu \mathrm{M}$ were evaluated using an unpaired Student's two-tailed t-test, where ${ }^{*} p<0.05,{ }^{* *} p<0.01,{ }^{* * *} p<0.001$

to bladder overactivity. Treatment with $\mathrm{PGF}_{2 \alpha}$ showed minimal increases at a concentration of $1 \mu \mathrm{M}$, yet responses were significantly enhanced in both U\&LP and detrusor when increased to $10 \mu \mathrm{M}$. At the smaller concentration of $1 \mu \mathrm{M}$, treatment with $\mathrm{TXA}_{2}$ reached maximal contractile responses, and as such, was not enhanced at the higher agonist concentration of $10 \mu \mathrm{M}$. This was not the case with detrusor preparations, wherein the higher concentration of $\mathrm{TXA}_{2}(10 \mu \mathrm{M})$ resulted in significantly enhanced contractions. The responses observed in porcine tissue in response to $\mathrm{PGF}_{2 \alpha}$, and $\mathrm{TXA}_{2}$ are consistent with the Palea [25] findings. In addition, our study has established that U\&LP isolated tissue is also capable of responding and producing definite increases in tonic contractions in response to these prostaglandin agonists.

Of the five prostaglandins, $\mathrm{PGD}_{2}$ and $\mathrm{PGI}_{2}$ had the smallest effect on both tonic contractions and spontaneous activity. This lack of increases to the tonic contractions or spontaneous contractile frequency may be explained by $\mathrm{PGD}_{2}$ having potential inhibitory actions via the stimulation of DP receptor [26]. An explanation for the small contractile effects observed in our study in response to $\mathrm{PGI}_{2}$, the main prostaglandin synthesised in the human bladder [14, 27], is that the aqueous solutions of $\mathrm{PGI}_{2}$ are extremely chemically unstable with a relatively short half-life, depending on the buffer concentration [28]. As such, future studies utilising more chemically stable $\mathrm{PGI}_{2}$ agonist analogous might provide further insights into the actions of this inflammatory mediator on the urinary bladder.

\section{Conclusions}

The urinary bladder is capable of responding to all five major prostaglandins produced in the urinary bladder. Out of these prostaglandins, $\mathrm{PGE}_{2}$ and $\mathrm{PGF}_{2 \alpha}$ had the 


\section{Prostaglandin $\mathrm{D}_{2}$}
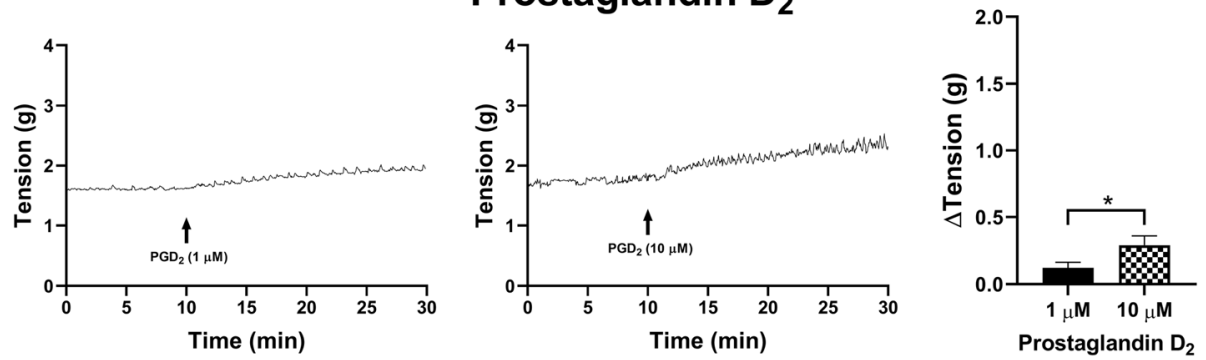

\section{Prostaglandin $\mathrm{I}_{2}$}
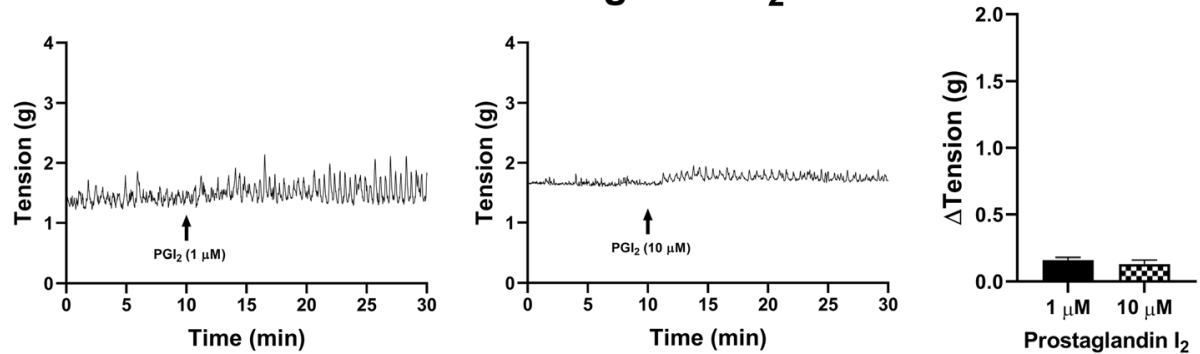

Fig. 5 Detrusor changes in tonic contractions in response to the treatment with $1 \mu \mathrm{M}$ and $10 \mu \mathrm{M}$ of prostaglandin agonists $\mathrm{D}_{2}$ (top row) and $\mathrm{I}_{2}$ (bottom row). Sample traces of responses observed to two concentrations of a prostaglandin agonist (left \& middle columns). Increases in the tonic contractions after treatment with an agonist are represented as mean change \pm SEM (right column). Significant changes in the tonic contractions between $1 \mu \mathrm{M}$ and $10 \mu \mathrm{M}$ were evaluated using an unpaired Student's t-test, where ${ }^{*} p<0.05,{ }^{* *} p<0.001$

most significant impact on both contraction and increases to the spontaneous contractile frequency in the U\&LP. All five prostaglandin receptor agonists were also capable of inducing spontaneous phasic contractions in otherwise quiescent detrusor tissue strips.

\section{Abbreviations}

PG: Prostaglandin; IC/BPS: Interstitial cystitis/bladder pain syndrome;

OAB: Overactive bladder; U\&LP: Urothelium and lamina propria;

TX: Thromboxane

\section{Acknowledgements}

This research was supported by the Australian Bladder Foundation managed by the Continence Foundation of Australia. ZS was supported by an Australian Government Research Training Program Scholarship.

\section{Authors' contributions}

Data was collected by ZS. CM, RCW and ZS were all equally responsible for the study design, data analysis, and preparation of manuscript. All authors read and approved the manuscript.

\section{Funding}

This research was supported by the Australian Bladder Foundation managed by the Continence Foundation of Australia. ZS was supported by an Australian Government Research Training Program Scholarship. The funding bodies had no role in the design of the study and collection, analysis, and interpretation of data and in writing the manuscript.

\section{Availability of data and materials}

The datasets used and/or analysed during the current study are available from the corresponding author on reasonable request.

\section{Ethics approval and consent to participate}

All methods were carried out in accordance with relevant Australian guidelines and regulations, and all experimental protocols were in accordance the Australian Code of Practice for the Care and Use of Animals for Scientific Purpose [16]. As no animals were bred, harmed, culled, interfered, or interacted with as part of this research project, Animal Ethics Approval was not required for offal use [17].

\section{Consent for publication}

Not applicable.

\section{Competing interests}

The authors declare that they have no competing interests.

Received: 28 February 2020 Accepted: 22 April 2020

Published online: 29 April 2020

\section{References}

1. Gilmore NJ, Vane JR. Hormones released into the circulation when the urinary bladder of the anaesthetized dog is distended. Clin Sci. 1971:41:6983.

2. Rahnama'i MS, van Kerrebroeck PE, de Wachter SG, van Koeveringe GA. The role of prostanoids in urinary bladder physiology. Nat Rev Urol. 2012;9(5): 283-90.

3. Tanaka I, Nagase K, Tanase K, Aoki Y, Akino H, Yokoyama O. Improvement in neurogenic detrusor overactivity by peripheral $C$ fiber's suppression with cyclooxygenase inhibitors. J Urol. 2010;183(2):786-92.

4. Reyes AA, Klahr S. Bladder contributes to eicosanoids excreted in urine. Am J Phys. 1990;259(5 Pt 2):F859-F61.

5. Kim JC. Changes of urinary nerve growth factor and prostaglandins in male patients with overactive bladder symptom. Int J Urol. 2005;12:875-80.

6. Kim JC, Park EY, Seo SI, Park YH, Hwang TK. Nerve growth factor and prostaglandins in the urine of female patients with overactive bladder. J Urol. 2006;175:1773-6.

7. Andersson KE, Ek A, Persson CG. Effects of prostaglandins on the isolated human bladder and urethra. Acta Physiol Scand. 1977;100(2):165-71.

8. Ricciotti E, FitzGerald GA. Prostaglandins and inflammation. Arterioscler Thromb Vasc Biol. 2011:31(5):986-1000.

9. Khan MA, Thompson CS, Mumtaz FH, Jeremy JY, Morgan RJ, Mikhailidis DP. Role of prostaglandins in the urinary bladder: an update. Prostaglandins Leukot Essent Fat Acids. 1998;59(6):415-22. 
10. Rahnama'i MS, Van Koeveringe GA, Van Kerrebroeck PE. Overactive bladder syndrome and the potential role of prostaglandins and phosphodiesterases: an introduction. Nephrourol Mon. 2013;5(4):934-45.

11. Andersson KE. Overactive bladder - pharmacological aspects. Scand J Urol Nephrol Suppl. 2002;210:72-81.

12. Tilley SL, Coffman TM, Koller BH. Mixed messages: modulation of inflammation and immune responses by prostaglandins and thromboxanes. J Clin Invest. 2001;108(1):15-23.

13. Smith WL, Dewitt DL. Prostaglandin endoperoxide $\mathrm{H}$ synthases-1 and -2 . Adv Immunol. 1996;62:167-215.

14. Masunaga K. Prostaglandin E2 release from isolated bladder strips in rats with spinal cord injury. Int J Urol. 2006;13:271-6.

15. Jeremy JY. Eicosanoid synthesis by human urinary bladder mucosa: pathological implications. Br J Urol. 1987;59:36-9.

16. Australia Government. Australian code for the care and use of animals for scientific purposes 2013 [Available from: https://www.nhmrc.gov.au/aboutus/publications/australian-code-care-and-use-animals-scientific-purposes.

17. Queensland Government. Using Animals in Science 2016 [Available from: https://www.business.qld.gov.au/industries/farms-fishing-forestry/agriculture/ livestock/animal-welfare/animals-science/activities/dead-animals.

18. Stromberga Z, Chess-Williams R, Moro C. Histamine modulation of urinary bladder urothelium, lamina propria and detrusor contractile activity via $\mathrm{H} 1$ and H2 receptors. Sci Rep. 2019;9(1):3899.

19. Stromberga Z, Chess-Williams R, Moro C. Alterations in histamine responses between juvenile and adult urinary bladder urothelium, lamina propria and detrusor tissues. Sci Rep. 2020:10(1):4116.

20. Moro C, Edwards L, Chess-Williams R. 5-HT2A receptor enhancement of contractile activity of the porcine urothelium and lamina propria. Int J Urol. 2016;23(11):946-51.

21. Moro C, Chess-Williams R. Non-adrenergic, non-cholinergic, non-purinergic contractions of the urothelium/lamina propria of the pig bladder. Auton Autacoid Pharmacol. 2012;32(3 Pt 4):53-9.

22. Moro C, Uchiyama J, Chess-Williams R. Urothelial/lamina propria spontaneous activity and the role of M3 muscarinic receptors in mediating rate responses to stretch and carbachol. Urology. 2011:78(6):1442.e9-15.

23. Moro C, Leeds C, Chess-Williams R. Contractile activity of the bladder urothelium/lamina propria and its regulation by nitric oxide. Eur $J$ Pharmacol. 2012;674(2-3):445-9.

24. Lee $T$, Hedlund $P$, Newgreen $D$, Andersson KE. Urodynamic effects of a novel EP (1) receptor antagonist in normal rats and rats with bladder outlet obstruction. J Urol. 2007;177(4):1562-7.

25. Palea S. Pharmacological characterization of thromboxane and prostanoid receptors in human isolated urinary bladder. Br J Pharmacol. 1998;124:86572.

26. Guan NN, Svennersten K, de Verdier PJ, Wiklund NP, Gustafsson LE. Receptors involved in the modulation of Guinea pig urinary bladder motility by prostaglandin D2. Br J Pharmacol. 2015;172(16):4024-37.

27. Jeremy JY, Tsang V, Mikhailidis DP, Rogers H, Morgan RJ, Dandona P. Eicosanoid synthesis by human urinary bladder mucosa: pathological implications. Br J Urol. 1987:59(1):36-9.

28. Moncada S. Biology and therapeutic potential of prostacyclin. Stroke. 1983; 14(2):157-68.

\section{Publisher's Note}

Springer Nature remains neutral with regard to jurisdictional claims in published maps and institutional affiliations.

Ready to submit your research? Choose BMC and benefit from:

- fast, convenient online submission

- thorough peer review by experienced researchers in your field

- rapid publication on acceptance

- support for research data, including large and complex data types

- gold Open Access which fosters wider collaboration and increased citations

- maximum visibility for your research: over $100 \mathrm{M}$ website views per year

At BMC, research is always in progress.

Learn more biomedcentral.com/submissions 